This item was submitted to Loughborough's Research Repository by the author.

Items in Figshare are protected by copyright, with all rights reserved, unless otherwise indicated.

\title{
The first global merger wave and the enigma of Chinese performance
}

\section{PLEASE CITE THE PUBLISHED VERSION}

http://dx.doi.org/10.1017/mor.2016.10

\section{PUBLISHER}

(c) Cambridge University Press (CUP)

\section{VERSION}

AM (Accepted Manuscript)

\section{PUBLISHER STATEMENT}

This work is made available according to the conditions of the Creative Commons Attribution-NonCommercialNoDerivatives 4.0 International (CC BY-NC-ND 4.0) licence. Full details of this licence are available at: https://creativecommons.org/licenses/by-nc-nd/4.0/

\section{LICENCE}

CC BY-NC-ND 4.0

\section{REPOSITORY RECORD}

McCarthy, Killian J., Wilfred Dolfsma, and Utz Weitzel. 2019. "The First Global Merger Wave and the Enigma of Chinese Performance". figshare. https://hdl.handle.net/2134/20872. 
MOR-14-036R4

3 December 2015

\section{The First Global Merger Wave and the Enigma of Chinese Performance}

Killian J. McCarthy, ${ }^{1}$ Wilfred Dolfsma, ${ }^{2}$ and Utz Weitzel ${ }^{3}$

${ }^{1}$ University of Groningen, The Netherlands, ${ }^{2}$ Loughborough University London,UK, and

${ }^{3}$ Radboud University Nijmegen, The Netherlands

ABSTRACT The first five merger waves were US-led events. In this article we show that the largely over-looked sixth wave (2003-2008) emerged in all regions simultaneously. Because of this, and building upon interconnected literatures - which: (1) suggests that agency is a big predictor of merger performance; (2) distinguishes between three distinct governance traditions; and (3) argues that the Anglo-Saxon system puts the most effort into protecting investors and aligning interests, and the Confucian system the least - we predicted that Anglo-Saxon acquirers would create value in the sixth wave, and Confucian acquirers would destroy it. We find the opposite to be true and show that Chinese acquirers, in particular, created the most value in the sixth wave. In attempting to explain why, we find that China outperformed its Asian neighbors while doing the same thing, and outperformed its Western peers while doing what the literature suggests that they shouldn't do. This not only points to the limits of the generalizability of the existing literature, but supports the suggestion that China is 'different'. We call, therefore, for additional research into understanding Chinese and Confucian acquirers using the standard comparative merger data. 
KEYWORDS Asian mergers, mergers and acquisitions, merger performance, sixth wave

\section{INTRODUCTION}

There have been five well-documented merger 'waves' (Bouwman et al., 2009). ${ }^{[1]}$

The first (ca. 1895-1904) and second (ca. 1918-1929) waves were uniquely American events. The third (ca. 1960-1969) saw merger activity spread from the US to the UK, the fourth (ca. 1981-1989) saw activity spread from the US to the UK and onto Continental Europe, and the fifth (ca. 1991-2001) saw merger activity spread from the US, to the UK, onto Continental Europe, and then to Asia. Because it was the first to have touched all regions, the fifth wave has been characterised as the first 'global' wave (Martynova \& Renneboog, 2008).

In recent years, scholars have added a sixth wave (c.a 2003-2008) to this discussion. Beyond the description of its basic features (see e.g., Alexandridis, Mavrovitis, \& Travlos, 2012), however, the sixth wave has largely been ignored. The implicit suggestion is that the sixth wave was just more of the same: another US-led, global merger wave. The fifth wave, Mark II if you will. Using a sample of 13,486 acquisitions, spanning 60 countries, we challenge that assumption.

We argue, firstly, that while the first five waves were a reaction to American-based changes in the operating environment of the firm, the sixth was a reaction to more global changes. Building upon a tradition that describes merger waves in geographic terms (see e.g., Andrade, Mitchell, \& Stafford, 2001), we hypothesise that while the fifth wave may have 'spilled out' of the US, as all previous waves had, the sixth will have started in all major economic regions simultaneously. We demonstrate this to be an empirical fact by considering the timing of the wave across Asia, Europe, and North America, and suggest, therefore, that 
the sixth wave was not just another American-led merger wave; in fact, it was the first 'truly' global merger wave.

Next, and precisely because it arose in all major economic regions simultaneously, we reason that each region may have experienced its own 'version' of the global sixth wave. We move, therefore, to consider local differences in the expression/performance of the sixth wave.

Geographically defined continents, however, are heterogeneous concepts: Australia and China share little but a continent, which makes the discussion of an 'Asian' wave somewhat arbitrary. Drawing, therefore, on the literature which divides the world into 'systems' rather than regions (e.g., Begley and Tan, 2001; La Porta, Lopez-de-Silanes, Shleifer, \& Vishny, 2000; Miles \& Goo, 2013), we identify three distinct systems: the AngloSaxon, the Continental, and the Confucian systems. Doing so, for example, splits Australia and China, and places the former with the other Anglo-Saxon countries, such as the United Kingdom, and the latter with the other Confucian countries, such as Japan. Then, because the same governance literature suggests: (1) that one of the most important factors in explaining merger performance is the way in which investors are protected and managerial interests are aligned; and (2) that the Anglo-Saxon system puts the most effort into protecting investors and aligning interests, and the Confucian system the least, we predicted that Anglo-Saxon acquirers would create value in the sixth wave, and Confucian acquirers would destroy it. However, we find the opposite to be true.

We report that, in the sixth wave, the average Anglo-Saxon acquirer destroyed 5.8\% of its market value, while the average Continental and Confucian acquirer added $4.8 \%$ and $5.1 \%$, respectively. Looking at the major dealmakers in each of the three systems - that is, the US in the Anglo-Saxon system, France in the Continental system, and China in the Confucian 
system - we show, furthermore, that it was Chinese acquirers, and not just Confucian acquirers, that were the real winners. We report that, in the sixth wave, the average US acquirer destroyed $-3.8 \%$ of its market value, the average French acquirer neither created nor destroyed value, while the average Chinese acquirer added a stunning $+5.8 \%$ (or $\$ 93.6 \mathrm{~m}$ ). Perhaps even more surprisingly, and looking at the performance of these acquirers over a longer stretch of time (1990-2010), we find that while Confucian acquirers tended always to perform well, and Anglo-Saxon acquirers tended always to perform poorly, Chinese acquirers only emerged as star acquirers in the course of the sixth wave. In other words, the Chinese only learned to create value, through acquisitions, in the course of the sixth wave. ${ }^{[2]}$ These findings - coupled with the fact, firstly, that the Asian sixth wave emerged organically, and was not led by any other region, and the fact, secondly, that the Asian sixth wave was 292\% larger than the Asian fifth wave, while the North American and European sixth waves were both smaller than their fifths - lend credence to the suggestion that the sixth wave marked the emergence of Asia, and particularly of the China, as major players in the merger market.

We finish with an exploration of the Chinese sixth wave in which we compare Chinese and non-Chinese acquirers, using the standard set of merger performance explanatory variables. The results here again are surprising. Comparing China with its Asian neighbors we fail to find any significant differences between the types of deals done. Comparing China with its Western peers, however, we report significant differences, but our results suggest that China did everything that the literature suggests that they shouldn't do; they crossed borders, with inflated market values, and made hostile, all cash-financed deals. The fact that China outperformed its Asian neighbors, while ostensibly doing the same thing, and outperformed its Western peers while doing what the merger literature suggests that they shouldn't do not only points to the limits of the generalizability of the existing literature, but supports the suggestion that China is 'different' (Lin, Peng, Yang, \& Sun, 2009). 
Unfortunately, however, the standard merger data that we employ to describe the sixth wave does not appear discriminating enough to quantify this difference. We hint at some possible explanations, from a cultural and institutional perspective, and call, therefore, for additional comparative quantitative research.

In doing so, we make important contributions to a number of literatures. Firstly, and by describing the evolution of the sixth wave across 60 countries, we demonstrate the historical and academic significance of the largely overlooked sixth wave. Secondly, and by empirically describing regional differences in performance, we not only add to the literature on merger performance, which has, in general, 'focused on the M\&A markets of the USA and UK' (Moschieri \& Campa, 2009: 72), but add to the 'limited literature' (Nicholson \& Salaber, 2013) on the empirical comparison of mergers and merger performance across systems. Thirdly, and by empirically describing the performance of Asian, Confucian and Chinese acquirers, we add to the literature which tends to only describe non-Western markets 'using case studies and descriptive statistics' (Lin et al., 2009: 1114). Finally, and perhaps most importantly, and by failing to demonstrate differences between the features of the average Chinese and the average Confucian acquirer, despite demonstrating significant differences in performance, we point to the limits of the generalizability of the existing empirical literature, and to the importance of research on non-Western governance mechanisms (e.g., Chen, Chen, \& Huang, 2013). Our research suggests that there are lessons to be learnt from Chinese acquirers but what those lessons might be, at the moment, remains unclear.

\section{THEORETICAL BACKGROUND AND HYPOTHESES}

\section{Merger Waves}


Merger waves are intensive periods of mergers and acquisitions, followed by intervals of fewer deals (Bouwman, Fuller, \& Nain, 2009), and merger waves follow a predictable pattern (see e.g., Andrade et al., 2001; Gort, 1969; Jensen, 1986; Morck, Shleifer, \& Vishny, 1988): an exogenous shock alters the shape of the market; observing this, managers reposition their firm, using mergers and acquisitions; merger activity spikes as more firms follow suit; and the wave ends once the market has corrected for the shock, or when the opportunities have been exhausted.

\section{The Five American Merger Waves}

Merger waves were long seen as an American phenomenon, and with good reason.

The first two merger waves (ca. 1895-1904 and ca. 1918-1929) were uniquely American events (Eis, 1969; Markham, 1955; Nelson, 1959; Stigler, 1950; Thorp, 1941; Weston 1961;).

The first began in 1895, as a reaction to: (1) slackening demand and increased competition, which pushed firms to consolidate (Watkins, 1927); (2) the completion of the national rail network, which increased the geographical reach of the firm (Bain, 1944); and (3) the creation of a US capital market, which provided the capital necessary to fund a merger wave (Navin \& Sears, 1955). It peaked between 1889 and 1902, and ended in 1904, when a banking crisis removed the financial capital necessary to sustain the wave (Nelson, 1959).

The second wave began in 1918 as a reaction to: (1) the post-war economic boom and the capital that this brought (Gaughan, 2008); and (2) a revolution in transportation and communication - with the growth of motor vehicles, for example, and the proliferation of radios and telephones - which transformed local markets into national ones, and allowed for 
still greater economies of scale to be achieved (Markham, 1955; Stocking, 1955). It peaked in 1929, and ended with the Wall Street Crash of 1929 and the start of the Great Depression.

The third wave (ca. 1960-1969) was the first of the international waves. It started, in the US, in 1960, as a reaction to: (1) a 'bull' market, which provided finance (Weston, Mitchell, \& Mulheri, 2004); (2) tax loopholes, which allowed bidders to make all-stock acquisitions, and to increase their earnings per share, without incurring a higher tax liability (Matsusaka, 1993); and (3) accounting loopholes, which allowed for the creation of papergains (Briloff, 1970). It internationalised, and spread to the UK, because of: (1) the national push, in the UK, for convergence between the US and UK governance systems (Toms \& Wright, 2007); and (2) the rise of modern management science across the Anglo-Saxon world, which encouraged efficiency, cost-cutting and risk spreading, and taught how businesses 'ought' to be built (Weston \& Mansinghka, 1971). As such the third wave can be seen to be a US-led, Anglo-American merger wave (Gaughan, 2008). It peaked in 1967, and ended in 1969 with the introduction of the US Tax Reform Act (1969) and a crash in the stock market.

The fourth (ca. 1981-1989) wave was the second international wave. It started, in the US, in 1981, as a reaction to: (1) deregulation at the hands of the Regan Administration (1981-1988), which stimulated consolidation (Mitchell \& Mulherin, 1996); (2) financial innovations, in the form of the leveraged buyout (LBO), which allowed for the acquisition of large entrenched targets (Holmstrom \& Kaplan, 2001; Jarrell, Brickley, \& Netter, 1988); and (3) a realisation that many of the conglomerates, created in the third wave, were better off broken up (Baker, Ruback, \& Wurgler, 2004; Shleifer \& Vishny, 1991). The fourth wave spread from the US, to the UK, again because of an increasingly shared view on corporate governance standards (Toms \& Wright, 2007) and, for the first time, onto Continental Europe, which was itself going through a period of deregulation and liberalisation, with the 
creation of the Single Market (1986). As a result, the number of intra-European acquisitions tripled between 1986 and 1989 (European Commission, 1999). The fourth wave peaked in 1987 and ended in 1989 with a stock market crash, and the beginning of a mild recession (1990-1991) in the US.

Finally, the fifth wave (ca. 1991-2001), the third international wave, began in the US in mid-1991, as a reaction to: (1) a bull market, which provided the capital (Shleifer \& Vishny, 2003); (2) deregulation, which further opened the US market (Andrade et al., 2001); and (3) increasing levels of economic globalisation, which reduced the costs of making crossborder acquisitions (Holmstrom \& Kaplan, 2001; Jovanovic \& Rousseau, 2001) and allowed 'previously domestically-orientated' companies to make overseas acquisitions' (Martynova \& Renneboog, 2008:7). It is remarkable, because not only did an Asian merger market emerge for the first time in the fifth wave (Sundarsanam, 2003), but because the European market became 'about as large as its US counterpart' (Martynova \& Renneboog, 2008). As the US’s share of the global market decreased from $83 \%$ in 1989, to $43 \%$ in 1999, Europe's share increased from $11 \%$ to $47 \%$ and Asia's share grew from $1 \%$ to $6 \%$ (European Commission, 2001). Observing this, US commentators concluded that the fifth wave 'will likely be the last that can be considered, even crudely, a US Wave' (Black, 2000). The fifth wave peaked in 1999, ending in 2000 when financial markets collapsed, the global economy slowed, and corporate scandals (e.g., WorldCom, Enron, etc.) first made the headlines.

\section{The Global Sixth Wave}

Because it touched all regions, the fifth wave has been described as the first global merger wave, and the story ended as an American way of doing business was adopted globally. 
The emergence of a sixth wave (ca. 2003-2008), therefore, generated little interest. A number of authors mention the sixth wave (see e.g., Cartwright \& Schoenberg, 2006; Gaughan, 2008; Martynova and Renneboog, 2008), but Alexandridis et al. (2012) is, to the best of our knowledge, the only paper that explicitly describes the features of the sixth wave. Unfortunately, however, Alexandridis et al’s. (2012) only consider domestic US deals.

From the academic and business press, we know, however, that the sixth wave started 'in mid-2003 [when the] economic and financial markets [in the US, Europe, and Asia started to recover following] the downturn that began in 2000' (Martynova \& Renneboog, 2008). As interest rates fell, and 'credit [became] cheap', shareholders became 'keen, once more, on takeovers' (The Economist, Sept 3, 2005). And the pace of deal-making in the sixth wave was ‘feverish’ (The Economist, Sept 3, 2005): one deal was completed every 18 minutes in 2004, (Cartwright \& Schoenberg, 2006), at an estimated value of '\$10 billion a day' (The Economist, April 8, 2006). Activity peaked in 2005, and lasted until news of the 'sub-prime crisis' broke at the end of 2007. In 2008, and as a consequence, M\&A activity 'slumped significantly’ (McCarthy \& Dolfsma, 2012). American, European, and Asian markets lost $30 \%$ of their value in the first eight months of the year, and as uncertainty spread, 1,307 deals - worth \$911 billion - were withdrawn (Gaughan, 2008), and the sixth wave ended.

Brief though it may have been, the sixth wave was no ordinary merger wave. The first five waves, as mentioned, started in the US, as a reaction to changes in the US market, and increasingly spilled out from the US as the costs of internationalisation decreased. The sixth wave was made possible, however, by rapidly growing levels of globalisation, economic integration, historically low interest rates, in the US, Europe and Asia, and, globally, a willingness to engage in large-scale corporate restructuring (Alexandridis et al., 2012). Because these were not US features of the period, but characteristics of the then global economy, and because of the rising significance of the European and Asian merger markets 
in the course of the previous two waves, we expect that the sixth wave will not have 'spilled' out from America, but will have emerged organically, in each region. In other words:

Hypothesis 1: The sixth wave arose in all major regions simultaneously.

\section{On the Regional Expression of the Global Sixth Wave}

Despite its global character, and drawing on the literature which compares and contrasts institutional and legal systems (e.g., La Porta, Lopez-de-Silanes, Shleifer, \& Vishny, 1997), we suggest that any wave which emerges in multiple regions simultaneously is likely to have a distinctly regional profile.

Grouping countries geographically, however, in order to explore regional performance differences is ill-advised: Australia and China are geographically part of Asia, but Australia and China share little in terms of the sorts of features that are likely to impact the performance of a merger wave. ${ }^{[3]}$ Following a number of prior studies (e.g., Begley \& Tan, 2001; Cernat, 2004; Miles \& Goo, 2013; Mueller, 2006; Weimer \& Pape, 1999) we therefore group countries according to their corporate governance traditions, rather than their geographical locations, and identify three distinct and relatively homogenous governance systems: the Anglo-Saxon, the Continental European, and the Confucian systems. ${ }^{[4]}$ Doing so groups Australia with the other Anglo-Saxon countries, like the United Kingdom and the United States, and China with the other Confucian countries, like Japan and Korea. 
The questions then, however, are: (1) what system-level features are likely to impact the performance of a merger wave; and (2) how do those features vary across the three systems?

Two literatures are helpful here. The first suggests that while a number of firm- and deallevel features impact merger performance (see e.g., King, Dalton, Daily, \& Covin, 2004), one of the most important performance predictors is the way in the firm protects its investors (Alchian \& Demsetz, 1972; Berle \& Means, 1932; Jensen \& Meckling, 1976; Jensen \& Ruback, 1983). This literature - the agency literature - suggests that in the absence of an effective governance system - defined as a 'set of mechanisms through which outside investors protect themselves against expropriation by the insiders' (La Porta, Lopez-deSilanes, Shleifer, \& Vishny, 2002: 1150) - managers are more likely to destroy investor value, either because of 'bounded rationality' or because of 'bounded reliability'. In the former case, well-intentioned but poorly monitored managers destroy shareholder value because of, for example, overconfidence (Jensen, 1986; Roll, 1986), and in the latter case self-interested and poorly monitored managers destroy shareholder value in an effort to create managerial gains (Akerlof, 1970; Shleifer \& Vishny, 1989; Williamson, 1993). Agency problems, the literature suggests, can be corrected with: (1) incentive alignment, through, for example, performance related pay packages; and (2) monitoring, through internal mechanisms, such as the creation of a board of directors, and external mechanisms, such as stock market performance and the market for corporate control.

The second literature suggests that the nature of the incentive alignment problem, however, varies per system, as does the strength of the protection against that particular problem. In the Anglo-Saxon and Continental systems, for example, the alignment problem is referred to as the 'principal-agent' problem (Berle \& Means, 1933; Jensen \& Meckling, 
1976): there, dispersed shareholders with small shareholdings are not incentivized to monitor managers, making managers more likely to make self-serving acquisitions, aimed at maximizing managerial utility (Mueller, 1969; Rhoades, 1983; Trautwein, 1990). Both Anglo-Saxon and Continental acquirers suffer this problem. Because the Anglo-Saxon common law systems provide shareholders with better protection against this problem (La Porta et al., 2000), and because managers salaries are more likely to be linked to objective performance measures (Abowd \& Bognanno, 1995; Weimer, 1995), it is likely that AngloSaxon acquirers will outperform Continental acquirers, both in general, and in the sixth wave. In the Confucian world, however, a high degree of family ownership (Ahlstromet, Chen, \& Yeh, 2010; Heugens, van Essen, \& van Oosterhout, 2009; Peng \& Jiang, 2010; Schulze \& Gedajlovic, 2010; Zhang \& Ma, 2009) and political involvement/influence (Cui \& Jiang, 2010; Deng, 2007; Globerman \& Shapiro, 2009), made opaque by cross- and pyramidalownership structures (Carney, Gedajlovic, Heugens, van Essen, \& van Oosterhout, 2011), creates the so-called 'principal-principal' problem (Dharwadkar et al., 2000; Yoshikawa \& Phan, 2005; Young, Peng, Ahlstrom, Bruton, \& Jiang, 2008): 'large majority shareholders make decisions that appropriate value from the smaller minority shareholders, often by influencing board level decisions such as asset sales and purchases’ ( $\mathrm{Su}, \mathrm{Xu}, \&$ Phan, 2008: 18). Because Confucian legal systems in general, and the legal systems in emerging Confucian countries like China, in particular, are generally unequipped for handling these sorts of problems, ${ }^{[5]}$ and because objective performance measurement tools, such as stock markets, and other market-monitoring mechanisms do not play a major role in the Confucian world (Bosiot \& Child, 1996; Keister, 1998, 2009; Naughton, 2002; Rui \& Yip, 2008; Yiu, Lau, \& Bruton, 2007), it is likely that Confucian acquirers will destroy value with mergers and acquisitions. 
Differences in the way in which interests are aligned, and investors are protected, allow us, therefore, to hypothesise as to systematic performance differences in the sixth wave:

Hypothesis 2: Anglo-Saxon acquirers will have performed the best in the sixth wave, and Confucian acquirers will have performed the worst.

\section{METHODS}

\section{Sample}

We build our sample using the Thomson Reuters SDC database; the only database which reports sufficiently detailed data for comparative merger research. We refine it to include all deals: (1) announced between Jan, 1990 and Jan, 2010; (2) by Asian, European and North American acquirers for Asian, European and North American targets ${ }^{[6]}$; (3) with transaction values above US\$50 million. We only include deals: (4) for 100\% of the target; and (5) deals which do not involve recapitalization, a repurchase of own shares, or a spin-off to existing shareholders. In doing so, we build a sample of 13,488 acquisitions. Dropping deals in which the location of the acquiring firm is incorrectly specified reduces this to 13,486 acquisitions $^{[7]}$.

\section{Independent Variables}

Using the acquiring firm's location, we create indicator variables to identify each of the 60 countries in the sample. Using these, we then create the following indicator variables: 
Geographical variables. In terms of geographical regions, we assign all 60 countries to one of three regions. We classify 19 countries - including Australia, China and India - using the Asia dummy, 39 - such as France and the United Kingdom -with the European dummy, and we classify 2 - Canada and the United States - with the North American dummy.

Governance variables. In terms of governance systems, we classify as many countries as possible to one of three corporate governance traditions. We classify 10 countries - including Australia, Canada, Ireland, and the United States - with an Anglo-Saxon dummy, 6 countries - China, Japan, Taiwan, South Korea as well as the Special Autonomous Regions of Hong Kong and Macau - with the Confucian dummy, and 33 countries - including France, Germany and Italy - are classified with the Continental dummy. In doing so, we assign 49 countries to one of three corporate governance traditions, and drop 11 countries from the corporate governance analysis, because either the corporate governance tradition of the country in question was unclear, as in the case of Russia and Georgia, or because the country came from a corporate governance tradition outside of the three that we considered, as in the case of Thailand and the Philippines.

\section{INSERT FIGURE 1 HERE}

Using the geographic indicators we identify 9,312 North American, 2,811 European, and 1,363 Asian acquirers, and using the systems indicators we identify 11,240 Anglo-Saxon, 1,423 Continental, and 562 Confucian acquirers. Figure 1 illustrates how using this approach, China, for example, becomes a subset the Confucian world, which, in turn, becomes a subset of Asia, and therefore how two countries from the same region can be identified with different systems indicators. A similar situation occurs in Europe, where Ireland and the United Kingdom are labelled both as European, but Anglo-Saxon rather than Continental. 


\section{Wave Variables}

We follow Bouwman et al. (2009) in identifying merger waves.

First, and using the total deal value of all mergers and acquisitions reported by the Thomson SDC, we calculate monthly deal values for the period Jan 01, 1990 to Jan 01, 2010. Next, we correct for inflation, by dividing the total deal values by the inflation correction factor per month. Finally, we de-trend the data by removing the line of best fit of the previous three years from the real total deal value of the observed month. If the resultant deal value is above the average of all months, that month is defined, in this way, as a 'merger wave' month.

We identify all wave months with a Wave indicator variable. Then, we distinguish between the fifth and sixth waves by labelling all wave months in the period 1990-2000 as fifth wave months (Wave5) and those in the period 2000-2010 as sixth wave months (Wave6).

Finally, we distinguish between the North American (Wave_NA), European (Wave_Euro) and Asia-Pacific (Wave_Asia) geographic wave, as well as those in the AngloSaxon (Wave_Anglo), Continental (Wave_Cont), and Confucian (Wave_Conf) systems.

\section{Deal Performance}

Following the majority of merger performance studies (see Zollo and Miere, 2008 for an excellent review), we calculate performance using an event study methodology.

The event study posits that the value of an 'event' - in this case, a merger - can be estimated by comparing differences in the actual and expected performance of the acquiring firm. Expected performance is a forecast of how the firm should behave, in the absence of an 
event, given how it has behaved in the past. We forecast the acquirers' expected performance, based on its behaviour over the year prior to an event. Next, we record the acquirers' actual performance in the same period. Subtracting actual from expected performance, gives an estimate of the unexpected, or 'abnormal returns' to the acquiring firm. Abnormal returns are a measure of the change - positive or negative - in a firm's performance, associated with a particular event. Summing the abnormal returns over a predefined period, or window, leads to an expression referred to as a CAR, or cumulative abnormal return. We calculate CARs using the standard $(-20,+1)$ window to capture run-up (Schwert, 1996). If a merger was announced on a non-trading day, we code the subsequent trading day as the official announcement day.

We retrieve the stock-market data, necessary to complete an event study, using Datastream. Data availability, at this point, reduces the sample of events for which we could identify performance, to 10,394 deals. This includes 9,339 Anglo-Saxon deals, 351 Confucian deals, and 585 Continental deals. All CARs are winsorized, between $1 \%$ and $99 \%$, as is the convention in the literature, to remove the distortionary effects of extreme outliers.

\section{Deal Features / Performance Controls}

A number of factors are known to impact deal performance (see King et al., for a review).

We control for: (1) the market-to-book ratio of the acquiring firm (MB Ratio) - which is the acquirer's market value four weeks prior to the announcement divided by total assets because Rau and Vermaelen (1998) show 'value' firms, with high market-to-book ratio, perform better than 'glamour' firms, with low market-to-book ratio; (2) Relative Size of the acquiring and target firm - proxied as the logarithm of the acquirer's total assets over the last twelve months before the announcement, to the logarithm of the acquirer's total assets over 
the last twelve months before the announcement - because Moeller, Schlingemann, and Stulz (2005) show that larger deals perform poorly; (3) Cash Flow to the acquiring firm - which we calculate by dividing the acquirer's operating profits over the last twelve months by the acquirer's market value four weeks prior to the announcement - because Jensen (1986) shows that cash-rich firms underperform those constrained by the 'discipline of debt'; (4) the Methods of Payment - in terms of the percent cash versus stock payment - because Heron and Lie (2002) show that cash-financed deals outperform stock-financed deals; (5) a CrossBorder indicator - which distinguishes international deals from domestic deals - because Datta and Puia (1995) show that domestic deals outperform international deals; (6) an indicator of deal attitude (Hostile) - which we identify with an indicator variable, set equal to 1 if the deal was hostile or unsolicited - because Betton and Eckbo (2000) show that hostility impacts performance; (7) a measure of the Relatedness between the target and the acquiring firm - which we identify as the distance between the industrial classification codes of the target and the acquiring firm - because Chatterjee (1986) shows that related deals outperform unrelated deals; (8) an indicator of whether the deal was completed or withdrawn (Completed), because poorly performing deals are more likely to be withdrawn; (9) the number of bids, or the levels to which the deal was contested (No. Bids) because Betton and Eckbo (2000) show that contested bids perform poorly; (10) a Delay variable, which indicates the number of days between the announcement and effective dates, because deals which are completed with caution outperform those that are completed at speed; and (11) a measure of the Premiums paid to the target - which we calculate as the percentage difference between the value of the target four weeks prior to the deal and the price paid by the acquirer at the announcement - because Hitt and Pisano (2003) show that premiums impacts deal performance. 
All the necessary data is collected from Thomson, and winsorized, to remove outliers. Table 1 reports the pairwise correlation, the mean and standard deviation of all variables.

\section{RESULTS}

\section{On the Development of the Global Sixth Wave}

Figure 2 makes use of the full sample of 31,486 mergers and acquisitions in the period, and illustrates the rise and fall of the fifth and sixth waves, using both the absolute (grey) and inflation-adjusted, de-trended (black) monthly transaction values. In doing so, it visually supports, for example, Alexandridis et al. (2012), in recording a distinct sixth merger wave.

\section{FIGURE 2 HERE}

More interestingly, Figure 3 reports the development of the fifth and sixth waves at the regional level. In terms of numbers, we report that the Asian sixth wave was $292 \%$ larger than the fifth wave, while the North American and European sixth waves were, respectively, 42\% and 44\% smaller. Visually, Figure 3 clearly supports the suggestion that the fifth wave was led by North America, and we see three distinct spikes in activity in each of the three regions. In the sixth wave, it seems that North America and Europe slightly led Asia, but the spike in activity in the three regions was much more homogenous. We empirically test the suggestion that the sixth wave started in all regions simultaneously by calculating a number of auto-regressive integrated moving average (ARIMA) regression models, with heteroskedasticity-consistent estimators of variance. The results (available upon request) show that, in the fifth wave, North American acquirers led European acquirers by, on average, one month (ARIMA[1,2,0]: $\beta=0.398, p=0.000$ ), and European acquirers lead Asian acquirers by another month (ARIMA[2,2,0]: $\beta=0.439, p=0.001$ ). In the sixth wave, however, 
we find no statistically significant evidence $(p<0.01)$ to suggest that any one region led the other. In other words, we support our hypothesis on the global nature of the sixth wave. ${ }^{[8]}$

FIGURE 2 HERE

\section{On the Local Performance of the Sixth Wave}

Models 1-8 on Table 2 explore the performance of the sixth wave, making use of the subsample of mergers and acquisitions for which stock market performance could be calculated. The R-Squares, while at first glance low, are typical of event studies in general. ${ }^{[9]}$

Before interpreting the results, we check for multi-collinearity. Turning back to Table 1, we see that none of the correlations between the key variables is higher than 0.27 (Number of Bids and Levels of Relatedness). A variance inflation factor (VIF) test on the base model (Model 1) reveals that the highest VIF for a single variable is 1.43 (Deal Size) with a mean of 1.23. These values are well below the established cut-offs of 5.3 (Hair, Anderson, Tatham, \& Black, 1992) and 10 (Studenmund, 1992), and so we can conclude that multi-collinearity is not an issue.

Continuing, therefore, Model 2 adds the sixth wave indicator variable to the base model. The negative and significant coefficient suggests that deals in the sixth wave (20032008) underperformed those in the full period (1990-2010). This fits with existing evidence on both merger waves (e.g., Moeller et al., 2005) and on the sixth wave (Alexandridis et al., 2012).

TABLE 2 HERE

Models 3 to 5 move next to consider differences in performance according to the various corporate governance traditions. ${ }^{[10]}$ Model 3 reports on the performance of Anglo- 
Saxon acquirers - such as Australia, the United Kingdom and the United States - Model 4 reports on the performance of Continental European acquirers - such as France and Germany - and Model 5 reports on the performance of Confucian acquirers - such as China and Japan. The results suggest that sixth wave Anglo-Saxon acquirers, on average, destroyed $5.8 \%$ of their market value, while Continental acquirers added $4.8 \%$ and Confucian acquirers added 5.1\%. Given that the existing literature, which is based largely on the study of Anglo-Saxon acquirers, suggests that most acquisitions fail (see e.g., Moeller et al., 2005), the results for the Anglo-Saxon indicator are not surprising. The results for Continental and Confucian acquirers are surprising: they suggest not only that Confucian acquirers do the best deals, but hint at the fact that poor performance and high failure rates may be a particularly AngloSaxon problem.

Finally, Models 6 to 8 report on the performance of the major dealmakers in each of the three governance systems, in the period of the sixth wave; that is, the Unites States $(n=8,380)$ in the Anglo-Saxon system, France $(n=249)$ in the Continental system and China $(n=259)$ in the Confucian system. Model 6 reports that US sixth wave acquirers, on average, destroyed $-3.8 \%$ of their market value, Model 7 reports that French acquirers neither created nor destroyed value, and Model 8 reports that Chinese sixth wave acquirers, on average, added a stunning $+5.8 \%$ (or $\$ 93.6 \mathrm{~m}$ ) to their market value. This is a significant return on investment, given that the average Chinese deal in the period of the sixth wave was worth $\$ 733.6 \mathrm{~m}$.

In contrast to our expectation, therefore, we show that Confucian acquirers, in general, and Chinese acquirers, in particular, outperformed their Anglo-Saxon and Continental European peers. We therefore reject our hypothesis on the performance ranking of sixth wave acquirers. 


\section{DISCUSSION}

In terms of predictable findings, we: (1) confirm the existence of the sixth wave; and (2) show that it started in all major economic regions simultaneously. The latter point is our first contribution: we demonstrate that the sixth wave was not just another merger wave, but was, actually, the first wave to have emerged in all regions simultaneously. In doing so, we demonstrate the historical and academic significance of this largely overlooked event.

Next, and precisely because it arose on all continents simultaneously, we reasoned that there might be regional versions of the sixth wave. Using the corporate governance literature, we predicted that the transparency and legal protection afforded by the AngloSaxon system made Anglo-Saxon acquirers the most likely to create value, in the course of the sixth wave, and Confucian acquirers the least likely. Unexpectedly, our results suggest that the opposite is true: Confucian acquirers and, in particular, Chinese acquirers, created the most value.

\section{The Chinese Sixth Wave}

Additional tests. To better understand Chinese performance, we performed two additional tests: First, we compare the performance of these various sets of acquirers over a longer stretch of time - that is, in the period 1990-2010 - in order to detect systematic performance differences. Our results ${ }^{[11]}$ suggest that while Confucian acquirers tended always, on average, to create value, and Anglo-Saxon acquirers tended, on average, to destroy value, China only emerged as a star acquirer in the course of the sixth wave. In other words, while Confucian 
acquirers seem to have a certain je ne sais quoi when it comes to mergers, our results suggest that the Chinese only learned how to do deals well in the course of the sixth wave. ${ }^{[12]}$

\section{TABLE 3 HERE}

Second, and using our set of standard control variables, we compare Chinese sixth wave deals with those concluded by the 'others'. Table 3 reports the mean for each control variable, and the statistical significance between the Chinese mean and the 'others' mean.

Comparing Chinese acquirers with, for example, US acquirers, Table 3 reports that Chinese acquirers are more likely to: (1) have inflated market values, which Rau and Vermaelen (1989) suggest make for poor acquirers, relative to so-called 'value' firms; (2) to pay with cash, which Jensen (1986) suggests frees the firm from the 'discipline of debt', and leads to poor performing deals; and (3) are more likely to cross borders, which Zaheer (1995) suggests adds the liabilities of foreignness to the deal; (4) are more likely to make hostile acquisitions, which Betton and Eckbo (2000) link to integration difficulties, and sub-par performance. The only plus on the Chinese side, as compared to US acquirers, is that the Chinese are less likely to complete a deal, which perhaps can be interpreted as being more willing to walk away from a bad deal. A similar story emerges when comparing Chinese and French acquirers, and indeed when comparing Chinese acquirers with those in the AngloSaxon and Continental systems, and those in the North American and European regions. The result is somewhat of a paradox: China seems to be doing what the empirical literature warns against, but in doing what it is doing, the Chinese are enjoying the best performance.

Table 3 presents three other noteworthy comparisons. Firstly, Table 3 compares Chinese acquirers with non-Chinese Asian acquirers, and reports that the only statistically significant difference is that non-Chinese Asian acquirers are more willing to complete deals. In the other categories, the Chinese and the non-Chinese Asians make statistically identical 
deals. Second, Table 3 compares Chinese acquirers with non-Chinese Confucian acquirers and reports that the only statistically significant difference between the two is the market-tobook ratios and in the methods of payments. In these instances, the non-Chinese Confucian acquirers are doing what the literature suggests, but in many of the other cases, again, the Chinese and the non-Chinese Confucian acquirers make statistically identical deals. Finally, and perhaps most interestingly, Table 3 reports on the differences - or rather the lack of differences - between sixth wave Chinese acquirers and non-sixth wave Chinese acquirers.

Two conclusions can be taken from this: (1) the do's and don’ts of the established merger literature do not apply to Chinese firms; and (2) the performance of sixth wave Chinese acquirers differs significantly from that of its Asian and Confucian neighbors, and from Chinese acquirers outside of the sixth wave, but the usual set of control variables does not pick up what it is that the Chinese are doing different. In other words, the set of controls that we employ - which is based upon the study of Western firms - appears sufficient to point to inter-regional differences, between China and the West, but insufficient to point out intra-regional differences between China and its geographic and cultural neighbors. Because of this, the performance of Chinese acquirers in the sixth wave remains enigmatic.

Explaining the enigma of Chinese performance. There are five interlinked literatures, which are useful in explaining the performance of Chinese and Confucian acquirers, but which offer explanations that are not yet readily testable with the sorts of comparative merger data that we employ to describe the sixth wave.

The first suggests that although Confucian acquirers, from a Western perspective, may appear inefficient, they are 'fit for purpose' (Miles \& Goo, 2013). In the West, for example, family ownership has been equated with ineffectual management, but in Asia 
family ownership is said to act as a governance device, by placing family welfare ahead of personal interest (Jiang \& Peng, 2011). In the same way, cross- and pyramidal-ownership structures are, in the West, synonymous with outdated conglomerate management structures, but in Asia such corporate structures are said to enhance monitoring and, in the absence of efficient markets, can be used to overcome liquidity constraints, by allowing affiliated firms to pool and reallocate resources among those firms (Carney et al., 2011; Jiang \& Peng, 2011; Khanna \& Palepu, 2000 ). Such structures, Luo, Huang, and Wang (2011) suggest, lead to superior performance. In effect, the corporate groups that dominate many Asian companies today create the sorts of internal markets that were necessary for many Western acquirers in the 1960s (Martynova \& Renneboog, 2008). This governance literature, in other words, suggests that, in terms of governance structure, there isn’t a 'one best way'.

The second stream suggests that Confucian firms have a number of cultural features, which reduce the threat of agency, and the necessity for formal, Western-style governance structures. This stream of literature, in turn, is split into three interlinked parts. The first, flowing from Hofstede’s (1984; 2001; 2007) cultural dimensions, suggest that while every country differs in terms of the five cultural dimensions, ${ }^{[13]}$ Western culture, on the whole, tends to be individualistic and focused on the short-term, while Asian culture tends to be collectivist and long-term orientated. This means Western managers are, vis-e-vis Asian managers, more likely to act in a self-interested manner and are more likely to overinvest in short-term goals, and underinvest in long-term assets (Gelauff \& Den Broeder, 1996; Porter, 1992; Prodhan, 199). Asian managers, in other words, are more likely to make good acquisitions which are more likely to deliver longer-term performance (Luo et al., 2011).

The third literature, flowing from the study of Asian business practices (e.g., Fei, 1992; Hamilton, 1996; Kao, 1993; Zhang \& Keh, 2011), points to the importance of concepts like 'harmony' - epitomised by the Japanese idea of wa (和) - at the group-level 
(Alston, 1989), and 'relationships' - epitomised by the Chinese idea of guanxi (关系) - at the level of the individual ( Chung \& Hamilton, 2001; Hitt, Lee, \& Yucel, 2002; Lovett, Simmons, \& Kali, 1999). These concepts encourage trust, social reciprocity and mutual benefit, relationships, diligence and perseverance, and a long-term orientation (Hitt et al., 2002; Leung \& Brew, 2009; Park \& Luo, 2001; Redding, 1993; Rohwer, 1995; Yang \& Su, 2013). Both concepts are related, and are institutionally monitored and policed (Chen et al., 2013; Chung \& Hamilton, 2001; Szeto, 2010), and have been linked to enhanced firm performance (Luo, 1997; Luo et al., 2011; Yang \& Su, 2013). Hitt et al. (2002) go as far as suggesting that Asian firms may, culturally, have a competitive advantage over Western firms, when it comes to developing and leveraging firm-level social capital. Hitt et al. (2002) suggest that Asian firms are effective in selecting and managing alliance partners, and are more successful as a result, compared to Western firms, due to their increased social sensitivity. Clearly, such a sensitivity is likely to translate from alliance management to merger management. ${ }^{[14]}$

The fourth literature, flowing from the study of Confucian business practices, suggests that the five virtues encouraged by Confucianism - ren (仁), humanity or benevolence, yi (義), a belief in righteousness, li (i禮), propriety or ideal conduct, zhi (智), wisdom, and xin (信), trustworthiness - have a number of real-world business benefits (Miles \& Goo, 2013; Zhu \& Yao 2008). They suggest that while Western managers must be limited by codes of conduct and legal rules, in order to discourage self-interested behavior, the absence of Western governance institutions does not imply that Confucian managers will act in a self-interested way. Confucian societies expect their managers to behave well (Luo et al., 2011), and because of this societal pressure, Confucian managers are likely to make better deals. 
Together, these literatures suggest that Asian, Confucian, and Chinese firms are different to their Western peers. These literatures can be used to explain our findings, but unfortunately, they do not offer hypotheses which are testable with the sorts of data that we employ.

\section{Limitations and Future Research Directions}

As with all studies, our findings are subject to a number of important limitations which, in themselves, suggest a number of interesting future research questions. Most importantly, the level of our analysis might be said to overlook the real differences that we seek to explain.

We compare 13,486 acquisitions across 60 countries: (1) by standardising the set of explanatory variables that we employ; and by (2) sourcing standardised data from the Thomson SDC. In doing so, we aim to compare like-with-like, and look for statistical differences in the same variables across the different countries and regions. Our approach: (1) assumes that variables suggested by the literature, which has been built upon the study of American / Anglo-Saxon firms, is a globally appropriate list; and (2) that differences in these variables can be used to build a map of regional and country-level differences. Paradoxically, therefore, we assume that everything is the same in attempting to describe the difference.

A number of our result merit attention by future research. First, what did the Chinese do in the sixth wave that they didn't in the fifth? We find huge performance differences, but little variation in terms of deal characteristics. Secondly, why doesn't the literature on mergers and acquisitions apply to Chinese acquirers? We find that the Chinese did everything that the literature warns them not to do, but created more value in the process. Thirdly, and

related to both previous points, what data can be used to comparatively describe the 
behaviour of Chinese mergers and acquisitions? The existing literature explains Chinese performance in terms of within-firm behavioural practices, but suggests little in terms of testable hypotheses using a large panel of international mergers and acquisitions. We call for future researchers, therefore, to continue to explore Chinese mergers and acquisition, with an eye to developing internationally comparable data, to allow us to better understand Chinese performance.

Finally, and at the most general level, we hope that future researchers will build upon the limitations of this research, and will continue to explore the characteristics of non-AngloSaxon mergers and acquisitions so that in future we will not have to restrict non-Anglo-Saxon mergers and acquisitions to the Anglo-Saxon model which currently dominates the literature. Developing specifically Anglo-Saxon, Continental European and Confucian models, we believe, would serve to enrich our understanding of what acquisitions work and why.

\section{CONCLUSION}

By demonstrating: (1) that there was a sixth wave; (2) that this sixth wave started in all regions simultaneously; (3) that there were different 'versions' of the sixth wave; (4) that the Asian sixth wave was 292\% larger than its predecessor, while the North American and European sixth waves were both smaller; (5) that Asian, Confucian and Chinese acquirers performed, in that order, the best in the sixth wave; and (6) that the standard set of control variables cannot be used to explain what it is that the Chinese, in particular, actually did differently, this paper makes a number of contributions to the literature. Firstly, and by describing the evolution of the sixth wave across 60 countries, we demonstrate the historical and academic significance of the largely overlooked sixth wave. Secondly, and by 
empirically describing regional differences in performance, we not only add to the literature on merger performance, which has, in general, 'focused on the M\&A markets of the USA and UK' (Moschieri \& Campa, 2009: 72), but add to the 'limited literature' (Nicholson \& Salaber, 2013) on the empirical comparison of mergers and merger performance across systems. Thirdly, and by empirically describing the performance of Asian, Confucian and Chinese acquirers, we add to the literature which tends to only describe non-Western markets 'using case studies and descriptive statistics' (Lin et al., 2009: 1114). Finally, and perhaps most importantly, and by failing to demonstrate differences between the features of the average Chinese and the average Confucian acquirer, despite demonstrating significant differences in performance, we point to the limits of the generalizability of the existing empirical literature, and to the importance of research on non-Western governance mechanisms (e.g., Chen et al., 2013). Our research suggests that there are lessons to be learnt from Chinese acquirers but what those lessons might be, at the moment, remains unclear.

\section{NOTES}

\section{Acknowledgements: we would like to thank}

[1] While technically and legally different, terms like 'merger', 'acquisition', and 'takeover' are used interchangeably. Following the convention, we describe merger and acquisition waves as merger waves.

[2] We thank the reviewers for bringing this suggestion to our attention.

[3] We thank the reviewers for this point.

[4] It is clear that the term 'Anglo-Saxon' refers to a set of countries, which share a number of cultural and institutional features, such as the use the common-law system. Just as clearly, the term 'Continental' refers to a set of European countries, which share a number of cultural and institutional features, such as the use the civillaw system. The term 'Confucian', however, is less clear, as it can be used to describe a religion, a philosophy, or a cultural system. It is important to note, therefore, that we use the word 'Confucian' to identify a set of countries with a shared cultural heritage, in the same way that we might label Europe as being 'Christian'. In doing so, we would not suggest that all European managers are Christian. We would suggest, however, that all European cultures are based upon a set of values, norms, and beliefs, which have been heavily influenced by Christian values. These, in turn, are likely to be influence the governance system, which regulates - in a nontheistic way - the way in which a firm is run. In the same way, and in labelling China, Japan, Taiwan, South Korea as 'Confucian', we would suggest that these cultures are based upon a set of values, norms and beliefs, which have been heavily influenced by Confucian values. Doing so is inline, for example, with the Inglehart and Welzel's cultural distinctions, and prior research. We do not use the term Confucian, therefore, to ascribe any particular philosophical or religious belief. We recognise: (1) that we cannot account for the religious beliefs of 
the managers in our sample, given the level of our analysis; and (2) that other religious systems, such as Daoism, Buddhism, Islam, and Christianity, also play important cultural roles in the region.

[5] According to the Wall Street Journal, the Chinese legal system, for example, remains especially 'weak... [and Chinese] courts have an inconsistent record in protecting shareholder rights... [a situation complicated by the fact that] officials often ignore court decisions...'

[6] We do so because these three regions capture the vast majority of the global merger market

[7] For example, in the case when the acquirers region is listed as Europe, but the country is listed as South Africa.

[8] Interestingly, we note that because $90.9 \%$ of American, $76.6 \%$ of European, and $85 \%$ of Asian deals remain within the same geographical region / on the same continent, and a similarly disproportion amount of deals remain within the same governance system, we could use the target or the acquirers locations to paint similar pictures of the activity in the sixth wave. We thank the editor for pointing this fact out to us.

[9] For example: writing in the Journal of Finance, Moeller et al. (2005) use an event study, and OLS estimation, to investigate the performance of 6,596 mergers and acquisitions, and report adjusted R-squares of 2-5\% (p.775); writing in the Journal of International Economics, Morck and Yeung (1992) use an event study, and OLS estimation, to investigate the announcement of 322 internationalisations, and report R-squares of $0-4 \%$ (pg. 49); writing in the Strategic Management Journal, Muller and Kräussl (2010) use an event study, and OLS estimation, to study the announcement of 354 corporate disaster donations, and reports adjusted R-squares of 46\% (p.919); and writing in Research Policy, McNamara and Baden-Fuller (2007) use an event study, and OLS estimation, to investigate the financial returns to R\&D announcement by biotechnology firms, and report Rsquares of $1-7 \%$, using a sample of 180 firms, and 2-8\% using a sample of 237 firms. We accept, however, that even if our results fall within the range of what is normal for an event study, the implication of an R2=0.05 is that $95 \%$ of the variance in the dependent goes unexplained. We recognise this limitation, and hope that future researchers will pick up on it in future. We thank the editors from bringing this point to our attention.

[10] We test but do not provide results on the performance of acquirers in each of three geographical regions. Our results suggest that North American acquirers destroyed value in the sixth wave (-3.4\%), European acquirers neither created nor destroyed value, and Asian acquirers, on average, created value $(+4.8 \%)$ in the sixth wave.

[11] Not reported but available upon request

[12] We thank the reviewers for bringing this suggestion to our attention.

[13] That is, individualism versus collectivism, masculinity versus feminity, long-term versus short-term orientation, high versus low power-distance and risk-taking versus uncertainty avoidance

[14] A less positive possibility is that Asian managers -- by virtue of their relatively poor English skills (McKinsey, 2005; Selmer, 2006) -- are forced to take longer to integrate an acquisition, and research suggests that the more considered and deliberate the integration, the better the performance (Datta, 1991). We see evidence of delays in the difference between the announcement and completion dates; the average Anglo-Saxon acquirer takes 4 days to complete an announced deals, while the average Asian and the average Confucian acquirer takes 16 days between announcement and completion. We do not have the data necessary to test the hypothesis that Asian, Confucian and Chinese acquirers outperform the rest because they delay their integrations, but we hope that future research will pick up on this point. We thank the editors for the suggestion.

\section{REFERENCES}


Abowd, J., \& Bognanno, M. 1995. International differences in executive and managerial compensation. In R. B. Freeman \& L. F. Katz (Eds.). Differences and Changes in Wage Structures: 67-104. Chicago: University of Chicago Press.

Ahlstrom, D., Chen, S. J., \& Yeh, K. S. 2010. Managing in ethnic Chinese communities: Culture, institutions, and context. Asia Pacific Journal of Management, 27(3): 341354.

Akerlof, G. A. 1970. The Market for 'lemons': Quality uncertainty and the market mechanism. The Quarterly Journal of Economics, 84: 488-500.

Alchian, A. A., \& Demsetz, H. 1972. Production, information costs, and economic organization. The American Economic Review, 62(5): 777-795.

Alexandridis, G., Mavrovitis, C. F., \& Travlos, N. G. 2012. How have M\&As changed? Evidence from the sixth merger wave. The European Journal of Finance, 18(8): 663688.

Alston, J. P. 1989. Wa, guanxi, and inwha: Managerial practices in Japan, China, and Korea. Business Horizons, 32(2): 26-31.

Andrade, G., Mitchell, M., \& Stafford, E. 2001. New evidence and perspectives on mergers. The Journal of Economic Perspectives, 15(2): 103-120.

Bain, J. S. 1944. Industrial concentration and government antitrust policy. In H. F. Williamson (Ed.). The Growth of the American Economy: 616-630. New York: Prentice-Hall.

Baker, M., Ruback, R. S., \& Wurgler, J. 2004. Behavioral corporate finance: A survey. NBER Working Paper No. 10863. 
Begley, T. M., \& Tan, W. L. 2001. The socio-cultural environment for entrepreneurship: A comparison between East Asian and Anglo-Saxon countries. Journal of International Business Studies, 32(3): 537-553.

Berle, A. A., \& Means, G. C. 1933. The Modern Corporation and Private Property. New York: The Macmillan Company.

Betton, S., \& Eckbo, B. E. 2000. Toeholds, bid jumps, and expected payoffs in takeovers. The Review of Financial Studies, 13(4): 841-882.

Black, B. S. 2000. First international merger wave (and the fifth and last U.S. wave). University of Miami Law Review, 54(4): 799-818.

Boisot, M., \& Child, J. 1996. From fiefs to clans and network capitalism: Explaining China's emerging economic order. Administrative Science Quarterly, 41(4): 600-628.

Bouwman, C., Fuller, K., \& Nain, A. 2009. Market valuation and acquisition quality: Empirical evidence. Review of Financial Studies, 22(2): 633-679.

Briloff, A. J. 1970. Accounting practices and the merger movement. Notre Dame Lawyer, 45(4): 604-628.

Carney, M., Gedajlovic, E. R., Heugens, P., van Essen, M., \& van Oosterhout, J. H. 2011. Business group affiliation, performance, context, and strategy: A meta-analysis. Academy of Management Journal, 54(3): 437-460.

Cartwright, S., \& Schoenberg, R. 2006. Thirty years of mergers and acquisitions research: Recent advances and future opportunities. British Journal of Management, 17(S1): S1-S5.

Cernat, L. 2004. The emerging European corporate governance model: Anglo-Saxon, Continental, or still the century of diversity? Journal of European Public Policy, 11(1): 147-166. 
Chatterjee, S. 1986. Types of synergy and economic value: The impact of acquisitions on merging and rival firms. Strategic Management Journal, 7(2): 119-139.

Chen, C. C., Chen, X-P., \& Huang, S. 2013. Chinese guanxi: An integrative review and new directions for future research. Management and Organisation Review, 9(1): 167-207.

Chung, W. K., \& Hamilton, G. 2001. Social logic as business logic: Guanxi, trustworthiness and the embeddedness of Chinese business practices. In R. P. Appelbaum, W. L. F. Felsteiner, \& V. Gessner (Eds.). Rules and Networks: 302-349. Oxford: Hart Publishing.

Cui, L., \& Jiang, F. 2010. Behind ownership decision of Chinese outward FDI: Resources and institutions. Asia Pacific Journal of Management, 27(4): 751-774.

Datta, D. K. 1991. Organizational fit and acquisitions performance: Effects of postacquisitions integration. Strategic Management Journal, 12: 281-297.

Datta, D. K., \& Puia, G. 1995. Cross-border acquisitions: An examination of the influence of relatedness and cultural fit on shareholder value creation in U.S. acquiring firms. Management International Review, 35(4): 337-359.

Deng, P. 2007. Investing for strategic resources and its rationale: The case of outward FDI from Chinese companies. Business Horizons, 50(1): 71-81.

Dharwadkar, R., George, G. \& Brandes, P. 2000. Privatization in emerging economies: an agency theory perspective. Academy of Management Review, 25(3): 650-69.

Eis, C. 1969. The 1919-1930 merger movement in American industry. Journal of Law and Economics, 12(2): 267-296.

Fei, X. 1992. From the soil: The foundations of Chinese society: A translation of Fei Xiaotong's Xiangtu Zhongguo. Berkley \& Los Angeles, CA: University of California Press. 
Gaughan, P. A. 2007. Mergers, acquisitions, and corporate restructurings. Hoboken, NJ: John Wiley and Sons.

Gelauff, G. M. M., \& Den Broeder, C. 1996. Governance of stakeholder relationships. The German and Dutch experience. Centraal Plan Bureau: The Hague.

Globerman, S., \& Shapiro, D. 2009. Economic and strategic considerations surrounding Chinese FDI in the United States. Asia Pacific Journal of Management, 26(1): 163183.

Gort, M. 1969. An economic disturbance theory of mergers. Quarterly Journal of Economics, 83(4): 624-642.

Hair, J., Anderson, R., Tatham, R., \& Black, W. 1992. Multivariate data analysis. New York, NY: McMillan.

Hamilton, G. G. 1996. Asian business networks. New York: Walter de Gruyter.

Hennart, J. F., \& Larimo, J. 1998. The impact of culture on the strategy of multinational enterprises: Does national origin affect ownership decisions? Journal of International Business Studies, 29(3): 515-538.

Heron, R. A., \& Lie, E. 2002. Operating performance and the method of payment in takeovers. Journal of Financial and Quantitative Analysis, 37(1): 137-155.

Heugens, P., van Essen, M., \& van Oosterhout, J. 2009. Meta-analyzing ownership concentration and firm performance in Asia: Towards a more fine-grained understanding. Asia Pacific Journal of Management, 26(3): 481-512.

Hitt, M. A., Lee, H. U., \& Yucel, E. 2002. The importance of social capital to the management of multinational enterprise: Relational networks among Asian and western firms. Asia Pacific Journal of Management, 19(2-3): 353-372. 
Hitt, M. A., \& Pisano, V. 2003. The cross-border merger and acquisition strategy: A research perspective, management research. The Journal of the Iberoamerican Academy of Management, 1(2): 133-144.

Hofstede, G. 1984. Cultural dimensions in management and planning. Asia Pacific Journal of Management, 1(2): 81-99.

Hofstede, G. 2001. Culture’s consequences: Comparing values, behaviors, institutions, and organizations across nations. Thousand Oaks, CA: Sage.

Hofstede, G. 2004. Business goals and corporate governance. Asia Pacific Business Review, 10(3-4): 292-301.

Hofstede, G. 2007. Asian management in the 21st Century. Asian Pacific Journal of Management, 24(4): 411-420.

Holmström, B., \& Kaplan, S. N. 2001. Corporate governance and merger activity in the United States: making sense of the 1980s and 1990s. Journal of Economic Perspectives, 15(2): 121-144.

ICMG (International Capital Markets Group). 1995. International corporate governance: Who holds the reins? London: ICMG.

Jarrell, G. A., Brickley, J. A., \& Netter, J. M. 1988. The market for corporate control: The empirical evidence since 1980. Journal of Economic Perspectives, 2(1): 49-68.

Jensen, M. 1986. Agency costs of free cash flow, corporate finance, and takeovers. American Economic Review, 76(2): 323-329.

Jensen, M., \& Meckling, W. 1976. Theory of the firm: Managerial behavior, agency costs, and ownership structure. Journal of Financial Economics, 3: 305-360.

Jensen, M. C., \& Ruback, R. S. 1983. The market for corporate control: The scientific evidence. Journal of Financial Economics, 11(1): 5-50. 
Jiang, Y., \& Peng, M. W. 2011. Are family ownership and control in large firms good, bad, or irrelevant? Asia Pacific Journal of Management, 28(1): 15-39.

Jovanovic, B., \& Rousseau, P. L. 2001. Mergers and technological change: 1885-1998. Working paper No. 0116, Department of Economics, Vanderbilt University.

Kao, J. 1993. The worldwide web of Chinese business. Harvard Business Review, 71(2): 24-36.

Keister, L. A. 1998. Engineering growth: business group structure and firm performance in China’s transition economy. American Journal of Sociology, 104(2): 404-440.

Keister, L. A. 2009. Organizational research on market transition: A sociological approach. Asia Pacific Journal of Management, 26(4): 719-742.

Khanna, T., \& Palepu, K. 2000. Is group affiliation profitable in emerging markets? An analysis of Indian diversified business groups. Journal of Finance, 55(2): 867-891.

King, D. R., Dalton, D. R., Daily, C. M., \& Covin, J. G. 2004. Meta-analyses of postacquisition performance: Indications of unidentified moderators. Strategic Management Journal, 25(2): 187-200.

La Porta, R., Lopez-de-Silanes, F., Shleifer, A., \& Vishny, R. W. 1997. Legal determinants of external finance. Journal of Finance, 52(3): 1131-1150.

La Porta, R., Lopez-de-Silanes, F., Shleifer, A., Vishny, R. W. 1998. Law and finance. Journal of Political Economy, 106(6): 1113-1155.

La Porta, R., Lopez-de-Silanes, F., Shleifer, A., \& Vishny, R. 2000. Investor protection and corporate governance. Journal of Financial Economics, 58: 3-27.

La Porta, R., Lopez-de-Silanes, F., Shleifer, A., \& Vishny, R. 2002. Investor protection and corporate valuation. The Journal of Finance, 57(3): 1147-1170. 
Leung, K., \& Brew, F. P. 2009. A cultural analysis of harmony and conflict: toward an integrative model of conflict styles. In R. S. Wyers, C. Y. Chiu, and Y. Y. Hong (Eds.). Understanding Culture: Theory, Research and Application: 411-428. New York: Psychology Press.

Lin, Z. J., Peng, M. W., Yang, H., \& Sun, S. L. 2009. How do networks and learning drive M\&As? An institutional comparison between China and the United States. Strategic Management Journal, 30(10): 1113-1132.

Lovett, S., Simmons, L. C., \& Kali, R. 1999. Guanxi versus the market: Ethics and efficiency. Journal of International Business Studies, 30(2): 231-247.

Luo, Y., Huang, Y., \& Wang, S. L. 2011. Guanxi and organisational performance: A metaanalysis. Management and Organization Review, 8(1): 139-172.

Luo, Y. 1997. Guanxi and performance of foreign-invested enterprises in China: An empirical inquiry. Management International Review, 37(1): 51-71.

Markham J. 1955. Survey of the evidence and findings on mergers. In G. J. Stigler (Ed.). Business Concentration and Price Policy: 141-182. Boston: Princeton University Press.

Martynova, M., \& Renneboog, L. 2008. A century of corporate takeovers: what have we learned and where do we stand? Journal of Banking and Finance, 32(10): 2148-2177.

Matsusaka J. 1993. Takeover motives during the conglomerate merger wave. RAND Journal of Economics, 24(3): 357-379.

McCarthy, K. J., \& Dolfsma, W. A. 2012. Understanding mergers and acquisitions in the 21st century: A multidisciplinary approach. Houndsmill: Palgrave MacMillan.

McKinsey. 2005. Addressing China’s looming talent shortage. McKinsey Report. 
Miles, L., \& Goo, S. H. 2013. Corporate governance in Asian countries: Has Confucianism anything to offer? Business \& Society Review, 118(1): 23-45.

Mitchell, M., \& Mulherin, J. H. 1996. The impact of industry shocks on takeover and restructuring activity. Journal of Financial Economics, 41(2): 193-229.

Moeller, S. B., Schlingemann, F. P., \& Stulz, R. M. 2005. Wealth destruction on a massive scale? A study of acquiring-firm returns in the recent merger wave. Journal of Finance, 60(2): 757-782.

Morck, R., Shleifer, A., \& Vishny, R. W. 1988. Characteristics of hostile and friendly takeovers. In A. J. Auerbach (Ed.). Corporate Takeovers: Causes and Consequences: 101-136. Chicago: University of Chicago Press.

Moschieri, C., \& Campa, J. M. 2009. The European M\&A industry: A market in the process of construction. Academy of Management Perspectives, 23(4): 71-87.

Mueller, D. C. 1969. A theory of conglomerate mergers. Quarterly Journal of Economics, 83: 659.

Naughton, T. 2002. The role of stock markets in the Asian-Pacific Region. Asian-Pacific Economic Literature, 13(1): 22-35.

Navin, T. R., \& Sears, M. V. 1955. The rise of a market for industrial securities, 18871902. Business History Review, 29(2): 105-138.

Nelson, R. L. 1959. Merger movements in American industry, 1895-1954. Princeton: Princeton University Press.

Nicholson, R. R., \& Salaber, J. 2013. The motives and performance of cross-border acquirers from emerging economies: Comparison between Chinese and Indian firms. International Business Review, 22(6): 963-980. 
Park, S. H., \& Luo, Y. 2001. Guanxi and organizational dynamics: Organizational networking in Chinese firms. Strategic Management Journal, 22(5): 455-477.

Peng, M. W., \& Jiang, Y. 2010. Institutions behind family ownership and control in large firms. Journal of Management Studies, 47(2): 253-273.

Porter, M. E. 1992. Capital disadvantage: America's failing capital investment system. Harvard Business Review, 70(5): 65-82.

Porter, M. E. 1998. Clusters and the new economics of competition. Harvard Business Review, 76(6): 77-90.

Prodhan, B. 1993. Corporate governance and long-term performance. Corporate Governance: An International Review, 1(4): 172-177.

Rau, P., \& Vermaelen, T. 1998. Glamour, value and the post-acquisition performance of acquiring firms. Journal of Financial Economics, 49(2): 223-253.

Redding, S. G., \& Ng, M. 1983. The role of 'face' in the organizational perceptions of Chinese managers. International Studies of Management \& Organization, 13(3): 92123.

Rhoades, S. A. 1983. Power, empire building and mergers. Lexington, MA: DC Heath and Co.

Rohwer, J. 1996. Asia rising: Why America will prosper as Asia's economies boom. New York: Simon \& Schuster.

Roll, R. 1986. The hubris hypothesis of corporate takeovers. Journal of Business, 59(2): 197-216.

Rui, H., \& Yip, G. S. 2008. Foreign acquisitions by Chinese firms: a strategic intent perspective. Journal of World Business, 43(2): 213-226. 
Schulze, W. S., \& Gedajlovic, E. R. 2010. Whither family business? Journal of Management Studies, 47(2): 191-204.

Schwert, G. W. 1996. Markup pricing in mergers and acquisitions. Journal of Financial Economics, 41(2): 153-192.

Selmer, J. 2006. Language ability and adjustment: Western expatriates in China. Thunderbird International Business Review, 48(3): 347-368.

Shleifer, A., \& Vishny, R. W. 1991. Takeovers in the '60s and the '80s: Evidence and implications. Strategic Management Journal, 12(S2): 51-59.

Shleifer, A., \& Vishny, R.W. 1989. Management entrenchment: The case of managerspecific investments. Journal of Financial Economics, 25(1): 123-139.

Shleifer, A., \& Vishny, R. W. 2003. Stock market driven acquisitions. Journal of Financial Economics, 70(3): 295-311.

Stigler, G. 1950. Monopoly and oligopoly power by merger. American Economic Review, 40(2): 23-34.

Stocking, G. 1955. Comment. In G. Stigler (Ed.). Business Concentration and Price Policy. Princeton: Princeton University Press.

Su, Y., Xu, D., Phan, P. H. 2008, Principal-principal conflict in the governance of the Chinese public corporation. Management and Organization Review, 4(1): 17-38.

Sudarsanam, S. 2003. Creating value from mergers and acquisitions: The challenges. Harlow, UK: Prentice Hall/Financial Times.

Szeto, R. 2010. Chinese folk wisdom: implications for guarding against unethical practice by Chinese managers. Journal of Public Affairs, 10(3): 173-185.

The Economist. 2005. Europe's nascent merger boom. 3 September. 
The Economist. 2006. Once more unto the breach, dear clients, once more. 8 April.

Thorp, L. W. 1941. The increasing responsibility of management. Journal of Accountancy, 72(5): 403.

Toms, S., \& Wright, D. M. 2002. Corporate governance, strategy and structure in British business history. Business History, 44(3): 91-124.

Trautwein, F. 1990. Merger motives and merger prescriptions. Strategic Management Journal, 11: 283-295.

Watkins, M. 1927. Industrial Combinations and Public Policy. Cambridge: Cambridge University Press.

Weimer, J., \& Pape, J. C. 1999. A taxonomy of systems of corporate governance. Corporate Governance: An International Review, 7(2): 152-166.

Weston, J. F. 1961. The management of corporate capital: a review article. The Journal of Business, 34(2): 129-139.

Weston, J. F., \& Mansinghka, S. K. 1971. Tests of efficiency performance in conglomerate firms. Journal of Finance, 26(4): 919-936.

Weston, J.F., Mitchell, M. L., \& Mulherin, H. J. 2004. Takeovers, restructuring and corporate Governance. Upper Saddle River, NJ: Pearson Prentice Hall.

Oliver E. Williamson, 1993. The economic analysis of institutions and organisations in general and with respect to country studies. OECD Economics Department Working Papers 133, OECD Publishing.

Yang, Z., \& Su, C. 2013. Understanding Asian business strategy: Modeling institutionbased legitimacy-embedded efficiency. Journal of Business Research, 66(12): 23692374. 
Yiu, D. W., Lau, C. M., \& Bruton, G. D. 2007. International venturing by emerging economy firms: the effects of firm capabilities, home country networks, and corporate entrepreneurship. Journal of International Business Studies, 38(4): 519-540.

Yoshikawa, T., \& Phan, P. H. 2005. The effects of ownership and capital structure on board composition and strategic diversification in Japanese corporations. Corporate Governance: An International Review, 13: 303-312.

Young, M. N., Peng, M. W., Ahlstrom, D., Bruton, G.D., \& Jiang, Y. 2008. Corporate governance in emerging economies: a review of the principal-principal perspective. Journal of Management Studies, 45(1): 196-220.

Zaheer, S. 1995. Overcoming the liability of foreignness. The Academy of Management Journal, 38(2): 341-363.

Zhang, J., \& Keh, H. T. 2011. Interorganisational exchange in China: Organisational forms and governance mechanism Management and Organization Review, 6(1): 123-147.

Zhang, J., \& Ma, H. 2009. Adoption of professional management in Chinese family business: a multilevel analysis of impetuses and impediments. Asia Pacific Journal of Management, 26(1): 119-139.

Zhu, W. Z., \& Yao, Y. C. 2008. On the value of traditional Confucian culture and the value of modern CSR. International Journal of Business and Management, 3(2): 58-62.

Zollo, M., \& Meier, D. 2008. What is M\&A performance. The Academy of Management Perspectives, 22(3): 55-77. 


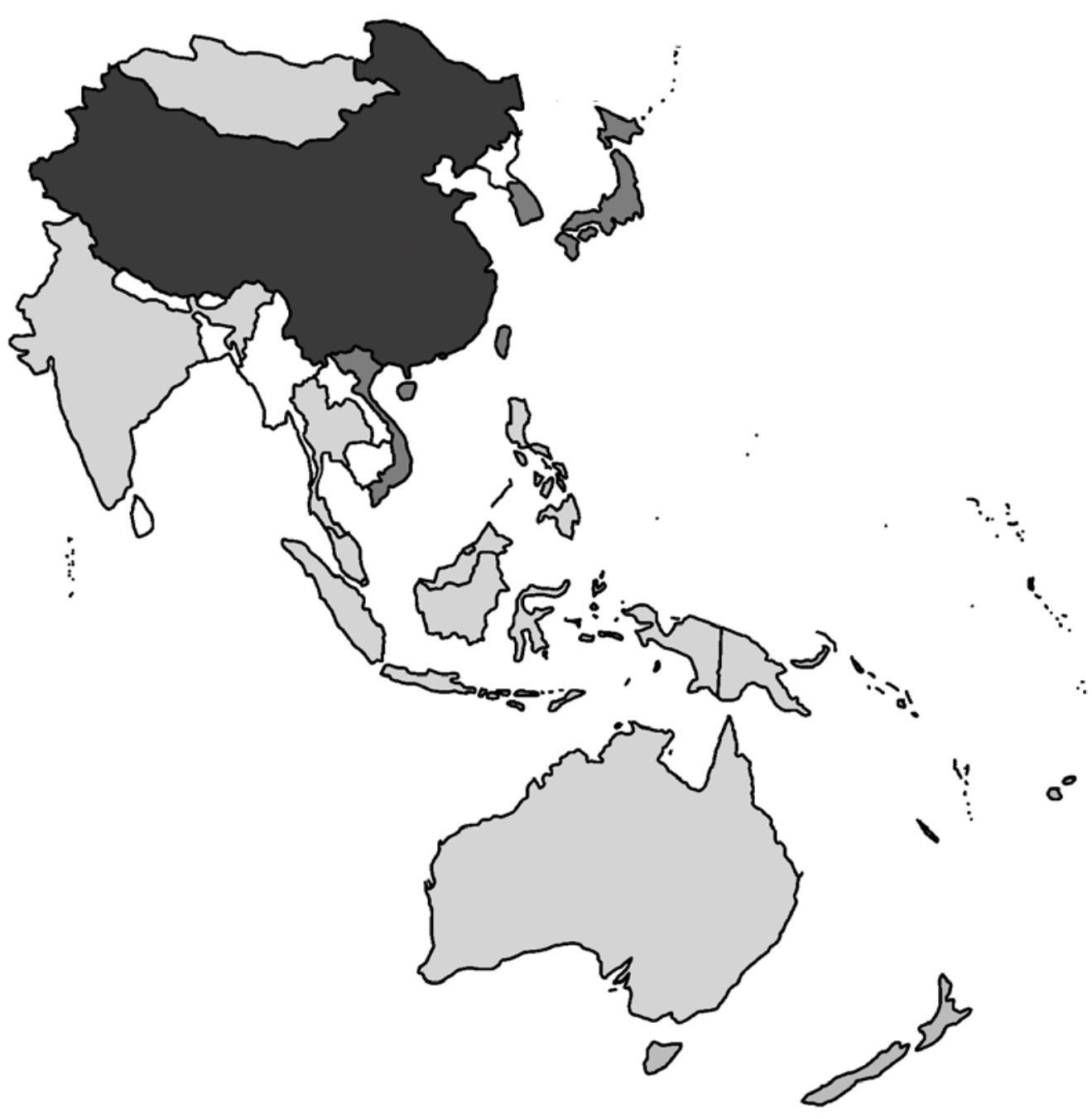

Figure 1. Countries, regions, and systems classifications

Notes: China (dark grey) and the Confucian world (grey) are sub-sets of the Asian countries for which we have data (light grey). White indicates no data. 
Table 1. Pairwise correlations \& descriptive statistics

\begin{tabular}{lllllllllllllllll} 
Mean & S.D. & Min & Max & 1 & 2 & 3 & 4 & 5 & 6 & 7 & 8 & 9 & 10 & 11 & 12 & 13 \\
\hline
\end{tabular}

\begin{tabular}{|c|c|c|c|c|c|c|c|c|c|c|c|c|c|c|c|c|c|c|}
\hline & & & & & & & & & & & & & & & & & & \\
\hline 1 & CAR $(20,1)$ & 0.02 & 0.19 & -0.50 & 0.97 & 1.00 & & & & & & & & & & & & \\
\hline 2 & Wave & 5.52 & 0.50 & 0 & 1 & $\begin{array}{c}0.01 \\
(0.72)\end{array}$ & 1.00 & & & & & & & & & & & \\
\hline 3 & MB Ratio & 3.01 & 7.88 & 0.05 & 64.26 & $\begin{array}{c}-0.01 \\
(0.21)\end{array}$ & $\begin{array}{l}-0.07 \\
(0.00)\end{array}$ & 1.00 & & & & & & & & & & \\
\hline 4 & Relative Size & 0.65 & 1.95 & 0.00 & 16.09 & $\begin{array}{c}0.23 \\
(0.00)\end{array}$ & $\begin{array}{c}0.05 \\
(0.01)\end{array}$ & $\begin{array}{c}0.05 \\
(0.00)\end{array}$ & 1.00 & & & & & & & & & \\
\hline 5 & Cash Flow & 0.10 & 0.13 & -0.50 & 0.42 & $\begin{array}{l}-0.08 \\
(0.00)\end{array}$ & $\begin{array}{l}-0.01 \\
(0.59)\end{array}$ & $\begin{array}{l}-0.19 \\
(0.00)\end{array}$ & $\begin{array}{l}-0.25 \\
(0.00)\end{array}$ & 1.00 & & & & & & & & \\
\hline 6 & Percent Cash & 42.41 & 44.15 & 0 & 100 & $\begin{array}{l}-0.03 \\
(0.00)\end{array}$ & $\begin{array}{c}0.14 \\
(0.00)\end{array}$ & $\begin{array}{l}-0.07 \\
(0.00)\end{array}$ & $\begin{array}{l}-0.09 \\
(0.00)\end{array}$ & $\begin{array}{c}0.14 \\
(0.00)\end{array}$ & 1.00 & & & & & & & \\
\hline 7 & Cross Border & 0.23 & 0.42 & 0 & 1 & $\begin{array}{c}0.03 \\
(0.00)\end{array}$ & $\begin{array}{c}0.05 \\
(0.00)\end{array}$ & $\begin{array}{c}0.03 \\
(0.00)\end{array}$ & $\begin{array}{c}0.01 \\
(0.45)\end{array}$ & $\begin{array}{c}0.04 \\
(0.00)\end{array}$ & $\begin{array}{c}0.14 \\
(0.00)\end{array}$ & 1.00 & & & & & & \\
\hline 8 & Hostility & 0.05 & 0.22 & 0 & 1 & $\begin{array}{c}0.01 \\
(0.43)\end{array}$ & $\begin{array}{c}0.01 \\
(0.44)\end{array}$ & $\begin{array}{l}-0.03 \\
(0.01)\end{array}$ & $\begin{array}{c}0.07 \\
(0.00)\end{array}$ & $\begin{array}{c}0.02 \\
(0.03)\end{array}$ & $\begin{array}{c}0.04 \\
(0.00)\end{array}$ & $\begin{array}{c}0.02 \\
(0.03)\end{array}$ & 1.00 & & & & & \\
\hline 9 & Relatedness & 1002 & 1505 & 0 & 8469 & $\begin{array}{l}-0.01 \\
(0.52)\end{array}$ & $\begin{array}{c}0.01 \\
(0.51)\end{array}$ & $\begin{array}{c}0.01 \\
(0.31)\end{array}$ & $\begin{array}{l}-0.03 \\
(0.00)\end{array}$ & $\begin{array}{c}0.04 \\
(0.00)\end{array}$ & $\begin{array}{l}-0.03 \\
(0.00)\end{array}$ & $\begin{array}{l}-0.03 \\
(0.00)\end{array}$ & $\begin{array}{c}0.01 \\
(0.29)\end{array}$ & 1.00 & & & & \\
\hline 10 & Completed & 0.85 & 0.36 & 0 & 1 & $\begin{array}{c}-0.02 \\
(0.06)\end{array}$ & $\begin{array}{l}-0.02 \\
(0.31)\end{array}$ & $\begin{array}{c}0.02 \\
(0.06)\end{array}$ & $\begin{array}{l}-0.13 \\
(0.00)\end{array}$ & $\begin{array}{c}0.06 \\
(0.00)\end{array}$ & $\begin{array}{c}0.01 \\
(0.19)\end{array}$ & $\begin{array}{l}-0.00 \\
(0.70)\end{array}$ & $\begin{array}{l}-0.29 \\
(0.00)\end{array}$ & $\begin{array}{c}0.02 \\
(0.03)\end{array}$ & 1.00 & & & \\
\hline 11 & No. Bids & 0.05 & 0.22 & 0 & 1 & $\begin{array}{c}-0.00 \\
(0.66)\end{array}$ & $\begin{array}{l}-0.02 \\
(0.18)\end{array}$ & $\begin{array}{l}-0.02 \\
(0.02)\end{array}$ & $\begin{array}{c}0.03 \\
(0.00)\end{array}$ & $\begin{array}{c}0.04 \\
(0.00)\end{array}$ & $\begin{array}{c}0.04 \\
(0.00)\end{array}$ & $\begin{array}{c}0.03 \\
(0.00)\end{array}$ & $\begin{array}{c}0.25 \\
(0.00)\end{array}$ & $\begin{array}{c}0.01 \\
(0.11)\end{array}$ & $\begin{array}{l}-0.27 \\
(0.00)\end{array}$ & 1.00 & & \\
\hline 12 & Delay & 8.72 & 54.75 & 0 & 1527 & $\begin{array}{l}-0.01 \\
(0.19)\end{array}$ & $\begin{array}{l}-0.01 \\
(0.58)\end{array}$ & $\begin{array}{l}-0.02 \\
(0.06)\end{array}$ & $\begin{array}{c}0.02 \\
(0.07)\end{array}$ & $\begin{array}{c}0.01 \\
(0.24)\end{array}$ & $\begin{array}{c}0.03 \\
(0.00)\end{array}$ & $\begin{array}{c}0.02 \\
(0.01)\end{array}$ & $\begin{array}{c}0.05 \\
(0.00)\end{array}$ & $\begin{array}{c}0.03 \\
(0.00)\end{array}$ & $\begin{array}{l}-0.04 \\
(0.00)\end{array}$ & $\begin{array}{c}0.16 \\
(0.00)\end{array}$ & 1.00 & \\
\hline 13 & Premiums & 32.16 & 58.85 & 0 & 1664 & $\begin{array}{c}0.01 \\
(0.60)\end{array}$ & $\begin{array}{l}-0.08 \\
(0.00)\end{array}$ & $\begin{array}{c}0.04 \\
(0.02)\end{array}$ & $\begin{array}{c}0.11 \\
(0.00)\end{array}$ & $\begin{array}{l}-0.01 \\
(0.61)\end{array}$ & $\begin{array}{c}0.05 \\
(0.00)\end{array}$ & $\begin{array}{c}0.05 \\
(0.00)\end{array}$ & $\begin{array}{c}0.03 \\
(0.01)\end{array}$ & $\begin{array}{l}-0.03 \\
(0.06)\end{array}$ & $\begin{array}{l}-0.04 \\
(0.00)\end{array}$ & $\begin{array}{c}0.06 \\
(0.00)\end{array}$ & $\begin{array}{c}0.12 \\
(0.00)\end{array}$ & 1.00 \\
\hline
\end{tabular}




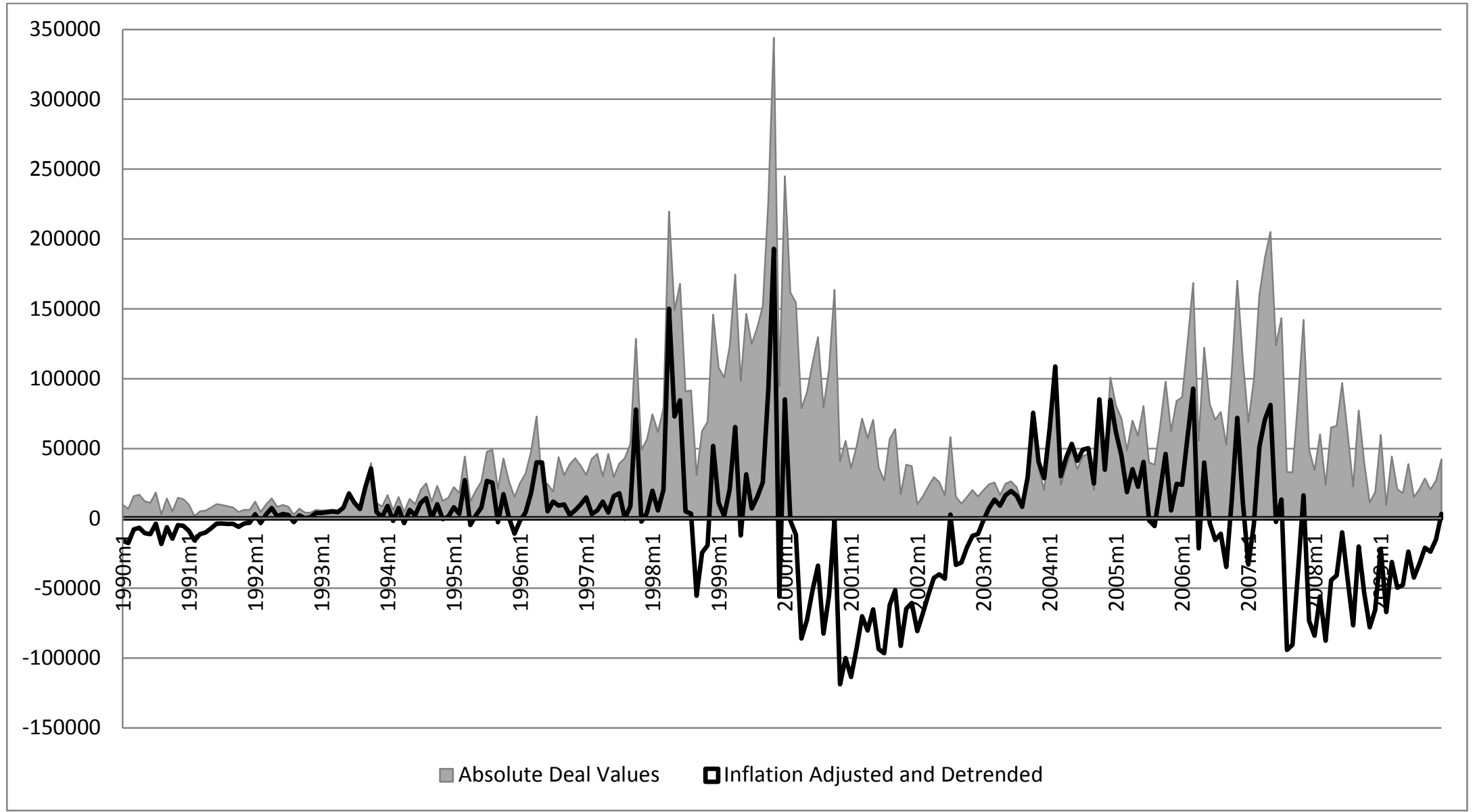

Figure 2. Absolute (grey areas) and inflation adjusted detrended transaction values (standardized), Jan 1990 - Jan 2010 


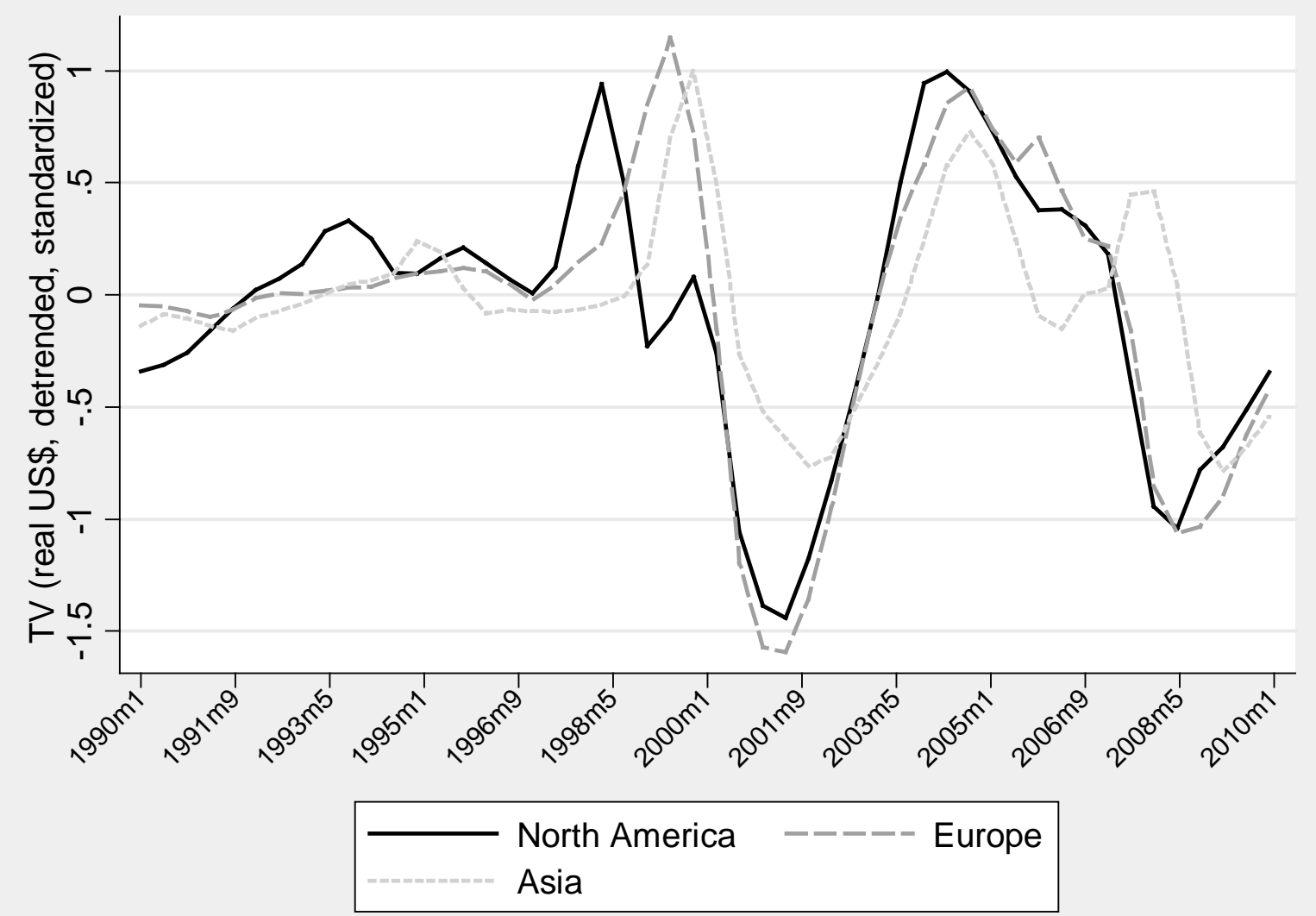

Figure 3. Inflation adjusted detrended transaction values (standardized), per Region, by Month, from Jan 1990 - Jan 2010 
Table 2. Regional differences in performance

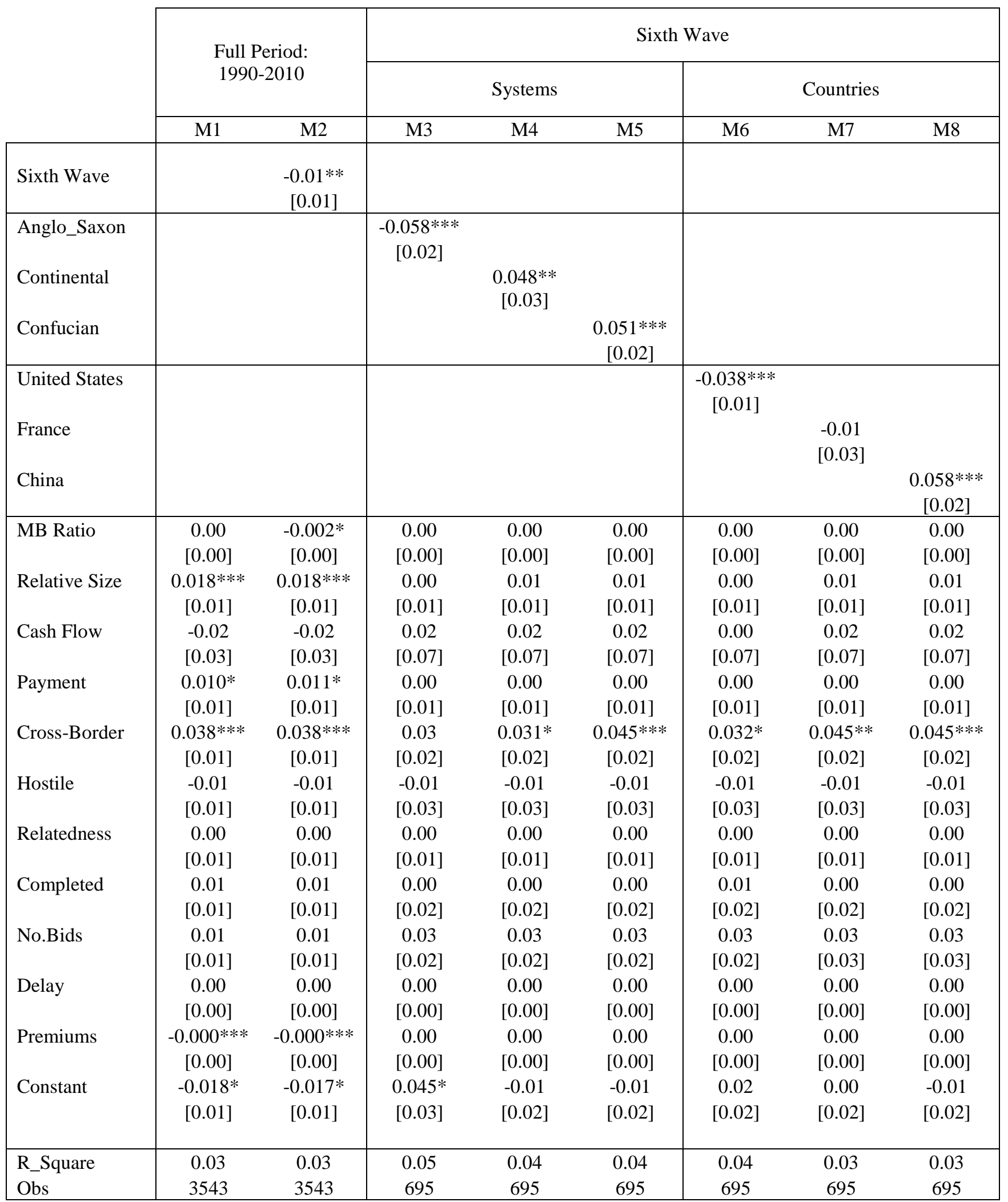


Table 3. Comparision of sixth wave

\begin{tabular}{|c|c|c|c|c|c|c|c|c|c|c|}
\hline & \multicolumn{9}{|c|}{ Sixth Wave } & \multirow{3}{*}{$\begin{array}{c}\text { Non-Sixtl } \\
\text { Wave } \\
\text { Chinese }\end{array}$} \\
\hline & \multirow[b]{2}{*}{ CHINA } & \multicolumn{3}{|c|}{ Continents } & \multicolumn{3}{|c|}{ Systems } & \multicolumn{2}{|c|}{ Countries } & \\
\hline & & $\begin{array}{c}\text { North } \\
\text { America }\end{array}$ & Europe & $\begin{array}{c}\text { Non- } \\
\text { Chinese } \\
\text { Asian } \\
\end{array}$ & $\begin{array}{l}\text { Anglo } \\
\text { Saxon }\end{array}$ & $\begin{array}{c}\text { Continental } \\
\text { European }\end{array}$ & $\begin{array}{c}\text { Non- } \\
\text { Chinese } \\
\text { Confucian } \\
\end{array}$ & $\begin{array}{l}\text { United } \\
\text { States }\end{array}$ & France & \\
\hline MB Ratio & 5.021 & $2.001^{* * *}$ & 4.318 & 3.146 & $2.479 *$ & 2.339 & $1.021^{* * *}$ & $2.037 * * *$ & $1.076^{* *}$ & 2.733 \\
\hline Relative Size & 0.774 & 0.576 & 0.973 & 1.444 & 0.692 & 0.700 & 0.604 & 0.510 & 0.467 & 1.655 \\
\hline Cash Flow & 0.088 & 0.099 & 0.105 & 0.072 & 0.097 & 0.106 & 0.087 & 0.093 & 0.109 & 0.055 \\
\hline Methods of Payment & 0.094 & $0.318^{* * *}$ & $0.306^{* *}$ & 0.547 & $0.312^{* * *}$ & $0.29 * *$ & 0.531 & $0.329 * * *$ & $0.273^{*}$ & 0.167 \\
\hline Cross Border & 0.281 & $0.143^{* *}$ & $0.566 * * *$ & 0.285 & 0.185 & $0.65^{* *}$ & 0.191 & $0.122 * * *$ & $0.757 * * *$ & 0.264 \\
\hline Hostile & 0.094 & $0.033^{* *}$ & 0.130 & 0.089 & 0.045 & 0.160 & 0.255 & $0.029 * *$ & 0.061 & 0.137 \\
\hline Relatedness & 0.313 & 0.376 & 0.319 & 0.309 & 0.369 & 0.320 & 0.021 & 0.354 & 0.364 & 0.260 \\
\hline Completed & 0.469 & $0.899 * * *$ & $0.761^{* * *}$ & $0.755^{* * *}$ & $0.874 * * *$ & $0.78^{* * *}$ & 0.234 & $0.910^{* * *}$ & $0.696^{*}$ & 0.573 \\
\hline No. Bids & 0.031 & 0.039 & 0.078 & 0.071 & 0.044 & 0.095 & 0.744 & 0.037 & 0.121 & 0.018 \\
\hline Premiums & 33.610 & 28.049 & 21.938 & 23.260 & 26.760 & 23.284 & 16.560 & 28.552 & 21.861 & 40.62 \\
\hline
\end{tabular}

